\title{
Development Control Regulations Compliance: Paradigm Change to Reinvent Disrupted Public Spaces and Make Future Great Place in Ado-Ekiti, Nigeria
}

\author{
Olufemi, Ojo-Fajuru*, Ambrose, Adebayo \\ School of Built Environment and Development Studies, University of KwaZulu-Natal, South Africa
}

Copyright $(2018$ by authors, all rights reserved. Authors agree that this article remains permanently open access under the terms of the Creative Commons Attribution License 4.0 International License

\begin{abstract}
Public spaces in the human society predate the built environment. Settlements expanding unto open spaces necessitate statutory control to ensure orderly development and mutual existence of various land uses. In developing countries like Nigeria, public spaces are subjected to encroachment and depletion. These result from rapid urbanization, population increase and space demand for human activities. Extant development control regulations seem ineffective in Ado-Ekiti, Ekiti State capital. Illegal development into public spaces is alarming, subtracting vital greenery and environmental quality from the city. This paper assesses the state of the environment to determine the extent of encroachment, and examines causal factors. Methods includes the review of existing planning laws pertaining to the establishment and maintenance of setbacks, open spaces and parks; and other related issues from literature sources. Questionnaire administration, interviews, focus group discussions and direct observation in selected city districts generated primary data. Findings reveal deplorable state of the environment occasioned by audacious encroachment of public spaces mainly by informal commercial activities. Ignorance of good quality environment, lack of effective governmental control, and people's desire for economic benefits are among factors responsible for these public spaces disruption. The research establishes that the city is devoid of greenery, while aesthetics, environmental quality, mobility, health, and livability are adversely affected. It is recommended that the State Government and municipal authority should strictly enforce extant statutory development control laws to reclaim lost socio-cultural spaces and revitalize urban green places. Functional 'trading/market' places should be incorporated into some of these spaces as development solution for informal sector economic activities, and thereby cater for the needs of itinerant traders and the urban populace. These measures, guided by a well-structured green city master plan, guarantee the return of the greens and biodiversity into the cityscape, and also provide
\end{abstract}

avenues for making future sense of a great place in Ado-Ekiti, the fledging capital city of Ekiti State, Nigeria.

Keywords Public Spaces, Lost Spaces, Reclamation, Greening, Placemaking, Inclusiveness

\section{Introduction}

Public spaces are integral components of human settlements from time immemorial. According to Fadamiro (2002), these include street space, park system, and the entire larger space in which the city exists. Public spaces are known to enhance urban design, civic identity, community cohesion, and quality of life (Sustasis Foundation, 2016). However, rapid urbanization has deprived cities of valuable public spaces and their inherent benefits. The spate of amorphous city expansion appears to have defied statutory control measures in Nigeria. Ojo-Fajuru and Adebayo (2016) confirm in Ado-Ekiti, in the southwestern geopolitical zone of Nigeria, that byelaws and regulations for guiding developmental processes are deemed ineffective, given the incidences of public space invasion and succession induced by non-compliance with due process, culminating to lost spaces. The warning of John Paul II (1979), that people shun sustainability and often tend 'to see no other meaning in their natural environment than what serves for immediate use and consumption', is already manifested in the contestation and personal aggrandizement of public spaces in the city. The incessant encroachment on public open spaces, squares, parks, setbacks and carriageways has led to the disappearance of greenery, which has eroded the quality of urban design and aesthetics in the capital city.

The paper discusses the importance of public spaces as they are well known all over the world so as to accentuate the inadequacy or total lack of these spaces in Ado-Ekiti. It 
is intended to explore the significance of such public spaces and the need to fill existing gaps and transform the city.

It is therefore deemed necessary to assess the existing state of the urban environment to determine the extent of encroachment on public open spaces, and the level of compliance with statutory provisions on development control in the city. This is intended to make a case for strict compliance with extant enactments, and reclaim disrupted public spaces for the reestablishment of green areas befitting of a state capital. Eventually, these measures will revive verdant and pleasurable places that are guaranteed to improve environmental quality, recreational potentialities, and livability, to reinvent Ado-Ekiti as world class Nigerian city of the future.

\section{Literature Review}

Planning laws are rules, regulations, statutes, byelaws, edicts and codes enacted to guide the trend of development to ensure conformity of land use activity, and promote order, efficiency, health, economy, convenience, safety and wellbeing in a particular place over a long period of time. Gray (2011) generalizes that environmental law as a body of laws, which seeks to protect or enhance the environment. Taking cue from the British Planning law, Section 91 of the Nigerian Urban and Regional Planning Law, Decree 88 of 1992 interprets development as the carrying out of any building, engineering, mining or other operations in, on, over or under any land, or the making of environmentally significant change in the use of any land or demolition of building including the felling of trees and the placing of free-standing erections used for the display of advertisements on the land, and the expression 'develop' with its grammatical variation shall be construed accordingly (Federal Government of Nigeria, 1992). This definition is replicated in Ekiti State Urban and Regional Planning and Development Law, No.16 of 2011, in which development translates to the carrying out of any building, mining or other operation in, on, over or under any land; or the making of any material change in the use of any land, building or structure, or conversion of land, building or structure from its established or approved use; or placement or display of urban furniture on the land, on building or structures; or making of any environmentally significant change in the use of any land, and demolition of buildings including the felling of trees (Ekiti State Government, 1997). The implication is that any particular operation or change of use that falls within the realm of development requires planning permission, indicating that any development that does not have the planning permission of the relevant planning agency constitutes illegal development (NITP, 2014).

Ojo-Fajuru and Olaseni (2015) disseminate development control is the process of implementing approved planning standards and regulations to ensure that development is carried out in accordance with approved planning standards and statutory provisions. In the United Kingdom, development control (DC), planning control, or development management (as it is known in Scotland) is the aspect of town and country planning that utilizes various categories of public-spirited plans, as reference documents, to grant or refuse planning permission aimed at regulating the use of land and erection of new buildings in juridical local governments. Accordingly, development control, seen as a mechanism to maintain standards (Aluko, 2011), is in line with the concept of quality control, exercised when the development taking place is guided towards attaining the physical development proposals contained in approved building plans, layout (land subdivision) schemes, or development plans. These development proposals are based on the planning standards approved by local planning authorities. Concisely, the process of implementing approved standards and regulations, with the objective of creating functionally efficient and aesthetically appealing environment, is termed development control. For development control to succeed, it is very important to ensure strict compliance with these statutory provisions in all ramifications.

Compliance is the attitude of abiding by laid down rules, regulations or norms. Legally, it is an act or process of complying with a demand or recommendation, or observance of official requirements (Law Dictionary, 2016). Within the context of this paper, compliance means conforming to a rule, such as a specification, policy, standard or law (Wikipedia, 2016a), and by extension, environmental compliance connotes conformity to environmental planning laws, regulations, standards and other requirements (Wikipedia, 2016b). Researchers find compliance becoming extremely difficult to attain in fast growing Nigerian urban centers. In a recent study, Ojo-Fajuru and Adebayo (2014) finds that both Ado-Ekiti and Akure, the contiguous capital city of Ondo State, experienced rapid growth and development. In effect, the low level of compliance is mostly attributed to population expansion and poor physical development control mechanism; hence the increasing elusiveness of what constitutes an effective compliance in the country. In his paper on the assessment of compliance to space standards for effective development control within the Lagos Metropolitan area, Aluko (2011) unveils variety of contraventions. Such include reckless shifting of building lines, construction of permanent structures, front shops and much unsightly development on road and utility setbacks, while the regulatory authorities have been foot dragging on prosecuting offenders.

In Festac Town, west of the Metropolis, research exposes numerous constraints militating against the effectiveness of development control measures, such as inadequate monitoring of development to ensure compliance with physical planning standards in respect of development permit (approval) granted. In effect, illegal 
conversion of residential buildings into mixed uses, comprising mainly residential/commercial is a common occurrence. This syndrome of non-adherence to planning regulations and standards constitutes major source of master plan distortion, and hindrance to effective development control in the predominantly planned estate (Ogundele et al., 2011). Ojo-Fajuru (2012) corroborates the disconnection between the statutory provisions of some extant laws on development control and their influence on the urban landscape in Lagos Metropolis. Research findings establish majority of development not conforming to relevant sections of the Town and Country Planning (Building Plan), L.S.L.N. No. 15 of 1986 on maximum plot coverage of development on any plot of land, which should not exceed $40 \%$, while the undeveloped portion should be devoted to landscaping and other surface treatment. Provisions of the law on general setbacks permissible, and the responsibility of developers to provide drainage and plant ornamental trees on the sidewalks abutting their properties are flagrantly contravened. Ignorance of these extant laws is manifested in spaces around buildings and structures, which are either encroached or left with scanty greenery, thereby accentuating the widening imbalance between man and nature in the metropolis.

Using Ogbomoso South Local Government, Oyo State, Nigeria as case study, Ibrahim and Toyobo (2014) assess the impact of development control on physical development planning, and discover high level of non-compliance with development control rules and regulations by developers in the area, as evident in inadequate building setbacks, airspaces, and encroachment of farmlands, among others. Enisan and Ogundiran (2014:46) identifies non-compliance with building bye-laws and regulations as the bane Nigeria's urban environment, notably in aspects of 'zoning, setbacks, building along utility lines and non-adherence to provision of adequate ventilation', which portend risk to life, environmental degradation, and aesthetical impairment. The study, which is on the implications of urban and regional planning laws on urban renewal projects carried out in Akure, capital of Ondo State, between 2007 and 2012 , indicates that the level of adherence to planning standards and regulations is extremely low. The proven reality of non-conformity with extant statutory provisions in the city negates the enthusiasm for the rule of law in the state generally. Similarly, a recent study (Adebayo, Jegede \& Ogundele 2015) indicates in some randomly selected local government areas in Nigeria's South-South Geo-political Zone, that the dilapidation and collapse of transportation land use infrastructure result from non-compliance with environmental laws, such as poor or lack of drainage channels along the road network, and construction of houses on natural drainage courses and floodable areas.

In Lagos Metropolis, the hydra headed issue of non-compliance piques professionals in the built environment in recent times. Observation shows that developers embark on development without recourse to approving authorities in flagrant disobedience of town planning laws and guidelines, leading to distortions in master plans of places such as Sari-Iganmu, Ikoyi, Lekki, and the encroachment into the Cowrie Creek at the Lagoon Front. Efforts of Lagos State Building Control Agency (LSBCA) in serving of necessary statutory notices including stop work order by have not deterred the developers who continued with the extension works on the existing buildings outside the statutory setback, including infringement on rights-of-way of high-tension power lines and drainage channels. This prompts the State Commissioner for Physical Planning and Urban Development to issue stern warning that 'this high level of impunity in the building industry must stop' (Alao, 2016:58).

The Ekiti State Urban and Regional Planning and Development Law No.3 of 2011 is the current planning law in use, which makes concise provisions for the establishing, controlling and maintaining setbacks and open spaces in towns and cities in the State. Rather than setting the setback requirements in terms of land use, it relates the use and development of land to conformity with stipulated minimum setbacks to developmental entities in the categories of water bodies, roadways, facilities and utilities, and other transportation routes. It is based on this premise that Section 34 subsection (a) unambiguously stipulates that one of the requirements that developers are expected to meet before planning permit is granted to commence building operation is to make provision for minimum setbacks, such as 30 metres (98.43 feet) to streams, 60 metres ( 196.85 feet) to rivers, and 100 metres (328.08 feet) to the edge of dams and large water bodies, purposely to safeguard life and properties from danger within the flood plains along the banks and shores of the hydrological features. The respective minimum setbacks to federal roads, state roads, and local roads are 50 metres (164.04 feet), 30 metres ( 98.43 feet), and 4.5 metres (14.76 feet), while the permissible minimum setbacks to low tension (domestic) power line, medium tension power line, and high tension power line are 4.5 metres (14.76 feet), 15 metres (49.21 feet), and 45 metres (147.64 feet) respectively. Telecommunications facilities such as GSM cell radio antennas, and optical fiber lines should be provided with 10 metres (32.81 feet), and 4.5 metres (14.76 feet) minimum setbacks, while utility lines including main water pipelines and underground cables should be given minimum setbacks distance of at least 15 metres (49.21 feet). Others include quarries, as well as other transportation routes like railways and gas pipelines should be setback to minimum observable distance of 100 metres (328.08 feet), 30 metres (98.43 feet), and 30 metres (98.43 feet) respectively (EKSG, 2011). In as much as these statutory requirements have implications on the availability of public open spaces, as well as the safety and security of lives and properties 
along the transportation routes, fluvial channels and communication facilities, there appears as if there is low level of compliance with these regulations given the common evasion of setback spaces for informal development.

In order to ensure strict compliance with minimum setback regulations, Section 27, subsection (1) of the Ekiti State Urban and Regional Planning and Development Law No.3 of 2011 makes it compulsory for the developer, whether private or government, to obtain development permit from the Planning Permit and Building Control Agency prior to the commencement of any construction work or physical development on any land in the State, even as section 28, subsection (6) reechoes a note of warning that ' $[\mathrm{n}] \mathrm{o}$ development shall be commenced by any government or its Agencies without obtaining a permit from the Planning Permit Authority'. It goes further that it is not enough to obtain development permit, but also to embark on the approved development, since the permit is invalidated if development did not commence within two years of the granting it in accordance with the statutory provisions of section 37, subsections (1), (2), (3), and (4) of the Law (EKSG, 2011). Unfortunately, these restrictive provisions seem not to go beyond the pages of the document, as development activities without appropriate permits appear to be the order of the day, whereby buildings and structures abound in unusual places and in unwholesome manners on setbacks and public spaces in most parts of the city. This calls for a change of attitude, and the need to embrace development control regulations compliance, to restore orderliness and functionality to Nigerian built environment.

The word 'change' means to become different; to make somebody or something different; to stop having one state, position or direction, and start having another; or to replace one thing, person, service, etc. with something new or different. Change also implies the act or result of something becoming different from an original state (Oxford Advanced Learner's Dictionary, 2000), such as social, economic, political, or ideological change. The present Administration in the Federal Government of Nigeria, propelled into office by the power of the people, is committed to a change agenda to correct mistakes of the past years of mismanagement, corruption, inefficiency, and enthrone good governance. The President declares that change is a process, which has begun, and will soon give way to abundant joy as the government puts the country firmly on the path of sustainable growth and development (Aziken et al. 2016). The Vice President reiterates that change was not a mere slogan, as the country could not survive going the way it had always gone (Osinbajo, 2016). It is within this concept of change that this paper seeks an attitudinal transformation as a departure from the culture of contravention, and a resolution to comply with the enforcement of development control regulations to the letter in Nigerian cities, including Ado-Ekiti. This guarantees the right atmosphere to forestall encroachment, reclaim lost public spaces, and restore sanity into the city.

Generally, public space is a space with unhindered access for people to interact and socialize such squares, plazas, parks, garden, playgrounds, roads, waterfronts and beaches. The Urban Dictionary (2016) pictures a public space as a place created 'for everybody to enjoy their coexistence and represent their collectivity and common interest without drowning or disaggregating their diversity'. It is of great importance that public spaces are powerful instruments of social inclusion, which any equitable city or town needs to offer in substantive quantity and accessible manner (Safer Spaces, 2016). Hence, the availability of public spaces is crucial to the social life of any human settlement. As stated by UN Habitat (2015:3), 'the character of a city is defined by its streets and public spaces', while 'the quality of life for people in cities is directly related to the state of its public spaces'.

More often than not, public space is synonymous to open space. In Nigeria, most squares, parks and open spaces are public spaces established and maintained by government or local authorities. City, town and village squares were in existence before colonization. Bascom (1962) attests that the Yorubas were living in 'city-like areas' before and during the colonial period, thereby making them one of the most urbanized people in Africa. He affirmed that around $22 \%$ of the population lived in cities of more than 100,000 people, while over $50 \%$ lived in settlements of 25,000 or more. Haven likened the rate of urbanization in 1950 to that of the US based on the burgeoning of major cities such as Ibadan, Osogbo, and Ogbomoso after the demise of Old Oyo Empire, he projected that the Yoruba nation would remain the most urbanized ethnic group in Africa. Mabogunje (1962) corroborates that Yorubas lived in cities of appreciable size before the onset of colonialism, while Breese (1966) affirms that the people experienced urbanization since 1856 when Yoruba cities of over 20,000 existed, including three of over 60,000 population, and by 1911 , the number of Yoruba cities had increased to eleven, with five of them having 60,000 population, and by 1952 , such cities increased to nine. These settlements had public spaces of various sizes and functions, Generally as a former colony, there is British influence on the Nigerian situation in the sense that the Nigerian Urban and Regional Planning Law, Decree 88 of 1992, the Country's major physical planning and development law, was fashioned after the 1932 British Town and Country Planning Law, thereby exerting some influence of British standards in the local culture and environment.

The typology of public spaces in terms of locality, ownership structure and functional classification vary in time and space. Obateru (2005) subdivides open space into private open space, and public open space, the former being an underdeveloped portion of a plot kept open for outdoor use, while the latter is an public space owned, leased to or put in trust of the community and used by the 
public for outdoor activities. In his study on open spaces in Akure, Fadamiro (2002) identifies natural and unused open spaces as mostly common, followed by recreational and commercial spaces, while religious, cultural and historical spaces are very few. This pattern is similar in neighboring Ado-Ekiti, where there is scanty provision for public spaces in form of consciously planned recreational areas and green spaces, while the few available ones, which are lacking in quality, are either poorly maintained or grossly abused (Ojo-Fajuru, 2003). Laws and regulations meant for the provision and maintenance of these public spaces seem ineffective, thereby depriving the populace of inherent benefits. These constitute the issues and challenges that this study is conceptualized to address.

The creation and maintenance of pleasurable public places is not the exclusive reserve of government. Rather, it is a public participatory development that involves the people, hence the relevance of the concept of placemaking. Placemaking is the practice of creating quality public spaces. As a vital people-oriented and community-targeted process, it elicits the support and involvement of public-spirited volunteers in the act of creating good quality public spaces. Kent (2015) posits that placemaking adopts the common sense approach that encourages and empowers the people to go beyond their own property, to conscientiously create and sustain valuable human places in their community. Placemaking is therefore a 'participatory and collaborative process', which involves interested parties, and allows the people to display their resourcefulness in the development of public spaces. As an 'open and inclusive process', placemaking promotes community's sense of belonging and the willingness to participate in its advancement. In South Africa, there are increasing number of placemaking-driven initiatives and interventions, which are intended to reclaim public open spaces, such as Johannesburg's Braamfontein Regeneration Project, and the Open Streets Cape Town movement as exemplified in Langa in depicted in Figure 1 below (Safer Spaces (2016). Similarly, the placemaking concept is indispensable to revitalize public spaces, reestablish greenery, and promote inclusion in the landscape and environment of Ado-Ekiti.

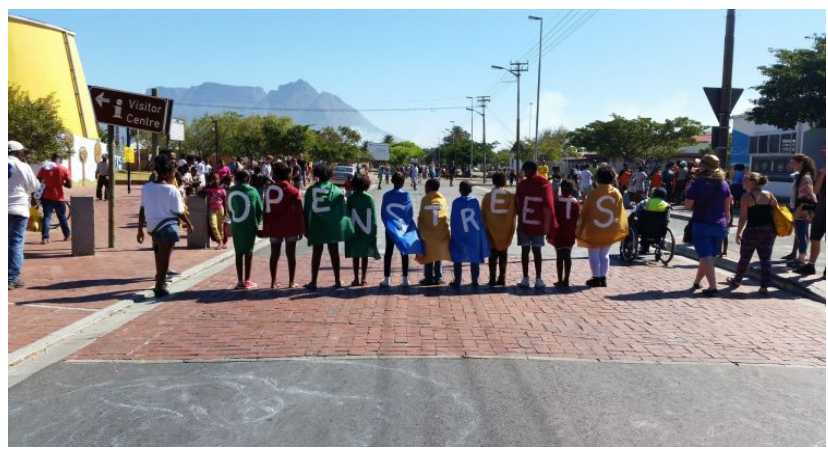

Source: Safer Spaces. Available at:

http://www.saferspaces.org.za/resources [accessed: 11 March 2016].

Figure 1.Promoting the use of public spaces-Open Streets in Langa, Cape Town (c) Open Streets Cape Town

\section{Objectives /Research Questions}

Some salient questions rose in the course of the study, to which answers are indispensable to the accomplishment of the research tasks, such as:

i) What is the structure of land use and the existing state of public spaces in Ado-Ekiti?

ii) Of what magnitude is the incidence of encroachment on public spaces in the city?

iii) Are there any factors attributable to the level of encroachment on these public open spaces?

iv) At what levels are the people aware and comply with extant regulations on development control in the city?

v) To what extent can the illegality of public open space encroachment be established to justify reclamation and enforce compliance in Ado-Ekiti?

vi) Can green landscaping and placemaking be used to reestablish reclaimed spaces into green areas in the capital city?

In order to answer these research questions, the following objectives are stated:

i) to assess the existing state of public spaces in the urban environment

ii) to evaluate the magnitude and factors of encroachment on public spaces

iii) to examine the levels of awareness and compliance with development control regulations in the city.

iv) to justify the need to reclaim encroached public spaces to reestablish green places.

\section{Key Approach to Challenges of Information Gathering and Data Collection}

The dearth of planning data and non-availability of current maps of land uses in Ado-Ekiti pose serious challenges to this research. In effect, it is difficult to determine the spatial structure and the existing states of public spaces in the city. The study relied on some old maps, which were updated manually by field survey as well as aerial views obtained from high points such as communication masts, hill crests and mountain summits, prior to their digitization by the Corel Draw and Arc GIS packages. The whole exercise was strenuous, risky, costly, time consuming and, at times, frustrating especially as regards obtaining necessary permissions from communication service providers to gain access to pylons at different locations of the city. Some reprieve was derived from satellite imageries obtained via internet, which were used to tract and map the trend of development in built up areas, and expansion into the city suburbs.

Some difficulties were also encountered during the field survey and data collection exercise. Some of the people using illegal structures or occupying encroached public 
spaces were foreseen to be apathetic and antagonistic to the survey, as they are wont to assume that the exercise has the backing of government, so as to eject them from their points of operation. In order to circumvent this, the researcher sought the consent of community heads and local resident association leaders to appeal to the people and convince them before the survey commenced, that the exercise was rather academic than governmental. In order for the study to gain more moral and ethical acceptance, some enumerators and field supervisors were selected within the localities of the survey exercise. In line with basic research ethics, respondents' right to willingly participate in the exercise, or decision to withdraw anytime, were protected. Assurance was given on the confidentiality of information volunteered. Finally, the Ministry of Lands was approached for a written permission in support of the field survey exercise.

\section{Approach and Methodology}

The identified categories of information and data required for the research were collected from primary and secondary sources. Relevant secondary data were extracted from published and unpublished works ranging from books, journals, conference proceedings, thesis, dissertations, to e-resources, imageries and maps through the internet. Field survey generated first-hand data from the delineated study area. The multi-stage sampling technique, which proved most appropriate for the research, commenced with the stratification of the city along district boundaries. The delineation into political wards for the 2007 General Elections in Nigeria (INEC, 2007) was adapted. Hence,
Ado-Ekiti LGA, a geographical unit in Ekiti Central I Federal Constituency, was subdivided into two federal constituencies. These are Ado I encompassing Ward A-Idofin, Ward B-Inisa, Ward C-Idolofin, Ward D-Ijigbo, Ward E-Ijoka, Ward F-Okeyinmi, and Ward G-Okeila; and Ado II comprising of Ward H-Ereguru, Ward I-Dallimore, Ward J-Okesa, Ward K-Irona, Ward L-Igbehin, and Ward M-Farm Settlement, all aligned with existing residential districts.

Using age, form and intensity of development as criteria in the spatial analysis of places carried out in Ado-Ekiti, neighborhoods were categorized along three contiguous morphological zones. These are old unplanned traditional core areas (COAs), new or recent neighboring colonial development areas within the last 30 to 50 years (NDAs), and planned post-colonial or contemporary residential estates (PREs) such as government reservation areas (GRAs), state housing estates (SHEs) and private housing estates (PHEs) as shown in Figure 2. It was based on these homogenous premises that some places were selected into the sampling frame.

In the unplanned core or old traditional areas, Ward A, Ward B, and Ward E from Ado I; and Ward H and Ward L in Ado II were picked respectively. Within new development areas, Ward D and Ward F were selected in Ado I, alongside Ward I and Ward K in Ado II. As for planned residential areas, made up of housing estates and G.R.As., Ward G in Ado I and Ward J in Ado II were selected. A total of $11 \mathrm{wards} /$ districts were selected into the sample frame. The selection of streets was based on the three road hierarchies within each selected district: primary, secondary, and tertiary roads as shown in Table 1. 




Source: Drawn by the Author based on field survey, July 2015.

Figure 2. Morphology of places as basis for neighbourhood selection into the sampling frame

Table 1. Houses selected on each selected street along morphological lines at the rate of one (1) in every four (4) houses (25\%), provide the bases for the final selection of respondents in the delineated study area in Ado-Ekiti.

\begin{tabular}{|c|c|c|c|c|c|c|c|c|c|c|}
\hline District & Major Road & $\begin{array}{l}\text { Total } \\
\text { No of } \\
\text { House }\end{array}$ & $\begin{array}{c}25 \% \\
\text { Selected }\end{array}$ & Minor Road & $\begin{array}{c}\text { Total } \\
\text { No of } \\
\text { Houses }\end{array}$ & $\begin{array}{c}25 \% \\
\text { Selected }\end{array}$ & Access road & $\begin{array}{c}\text { Total } \\
\text { No of } \\
\text { Houses }\end{array}$ & $\begin{array}{c}25 \% \\
\text { Selected }\end{array}$ & $\begin{array}{c}\text { Total } \\
\text { Selected } \\
\text { per } \\
\text { District }\end{array}$ \\
\hline Idofin & $\begin{array}{l}\text { Mathew } \\
\text { Street }\end{array}$ & 252 & 60 & Idemo Street & 143 & 36 & Idofin Street & 114 & 30 & 126 \\
\hline Inisa & $\begin{array}{l}\text { Odo Ado } \\
\text { Street }\end{array}$ & 372 & 90 & Inisa Street & 222 & 54 & Iyere Street & 168 & 42 & 186 \\
\hline Ijoka & $\begin{array}{c}\text { Orereowu } \\
\text { Street }\end{array}$ & 702 & 174 & Ajibade Lane & 588 & 150 & Orereowu & 258 & 66 & 390 \\
\hline Ereguru & Ogbon Oba & 606 & 150 & Ereguru Street & 654 & 162 & Ogbon Ado & 162 & 60 & 372 \\
\hline Igbehin & Igbehin Street & 750 & 186 & Igbehin & 408 & 102 & Atikankan & 294 & 72 & 360 \\
\hline Ijigbo & $\begin{array}{c}\text { Ajilosun } \\
\text { Street }\end{array}$ & 1014 & 252 & Okebola Street & 486 & 120 & Eribi Street & 270 & 66 & 438 \\
\hline Okeyinmi & $\begin{array}{c}\text { Okeyinmi } \\
\text { Street }\end{array}$ & 636 & 162 & $\begin{array}{c}\text { Okutagbokutaleri } \\
\text { Street }\end{array}$ & 300 & 72 & $\begin{array}{l}\text { OkeIla/AnuOdo/ } \\
\text { Okeyinmi Street }\end{array}$ & 234 & 60 & 294 \\
\hline Dallimore & $\begin{array}{l}\text { Dallimore } \\
\text { Street }\end{array}$ & 624 & 156 & Kajola Street & 510 & 126 & Oremeta & 336 & 84 & 366 \\
\hline Irona & Irona/Surulere & 1236 & 312 & $\begin{array}{c}\text { Ola Ajayi/Ekute/ } \\
\text { Waterworks Road }\end{array}$ & 1086 & 270 & $\begin{array}{c}\text { Irona/AtundaOlu/ } \\
\text { Oniyo Road }\end{array}$ & 522 & 132 & 714 \\
\hline $\begin{array}{l}\text { Oke-Ila } \\
\text { (S.H.E.) }\end{array}$ & State Road & 474 & 120 & $8^{\text {th }}$ Avenue & 288 & 72 & $7^{\text {th }}$ Avenue & 258 & 66 & 258 \\
\hline $\begin{array}{c}\text { Okesa } \\
\text { (G.R.A.) }\end{array}$ & $\begin{array}{c}\text { Secretariat } \\
\text { Road }\end{array}$ & 546 & 138 & $\begin{array}{c}\text { DejiAdegbite } \\
\text { Street }\end{array}$ & 240 & 60 & Onigari Street & 222 & 54 & 252 \\
\hline Total & 11 & 7212 & 1800 & 11 & 4932 & 1224 & 11 & 2922 & 732 & 3756 \\
\hline
\end{tabular}

Source: Author's compilation, June, 2015. 
House count conducted at street level paved way for the selection of twenty-five percent of houses in each street, boiling down to one in every four houses, having made a random selection of the first house. Out of 15,066 houses enumerated, 3,756 houses or $24.93 \%$, which approximates to $25 \%$, were selected. Assuming that the socio-economic indicators of households in the selected districts are similar (Olanrewaju, unpub.), one person, preferably the household head, was randomly picked in each of the selected houses yielded the 3,756 respondents selected for the study. Socio-economic and environmental survey of selected districts was conducted, using research tools such as questionnaire, key-informant interviews, observations, and physical linear measurements. The baseline data generated was used to determine the spatial structure of the study area, the availability, and the extent of encroachment on public open spaces in the capital city.

\section{Research Analysis \& Findings / Results}

Only 3,708 questionnaires were collected out of 3,756 administered. These were subjected to comprehensive sorting, following which only 3,324 questionnaires were accepted for SPSS collation and analysis, indicating a response rate of $88.50 \%$.

\subsection{The Existing State of Public Spaces in the Urban Environment}

The study reveals the dominance of residential land use in the spatial structure of Ado-Ekiti, wherein three distinctive morphological zones were identified. The sheer planlessness of the core areas and new development areas contrasts sharply with the planned residential estates in the peri-urban fringes of the city as shown in Figures 3 and 4.

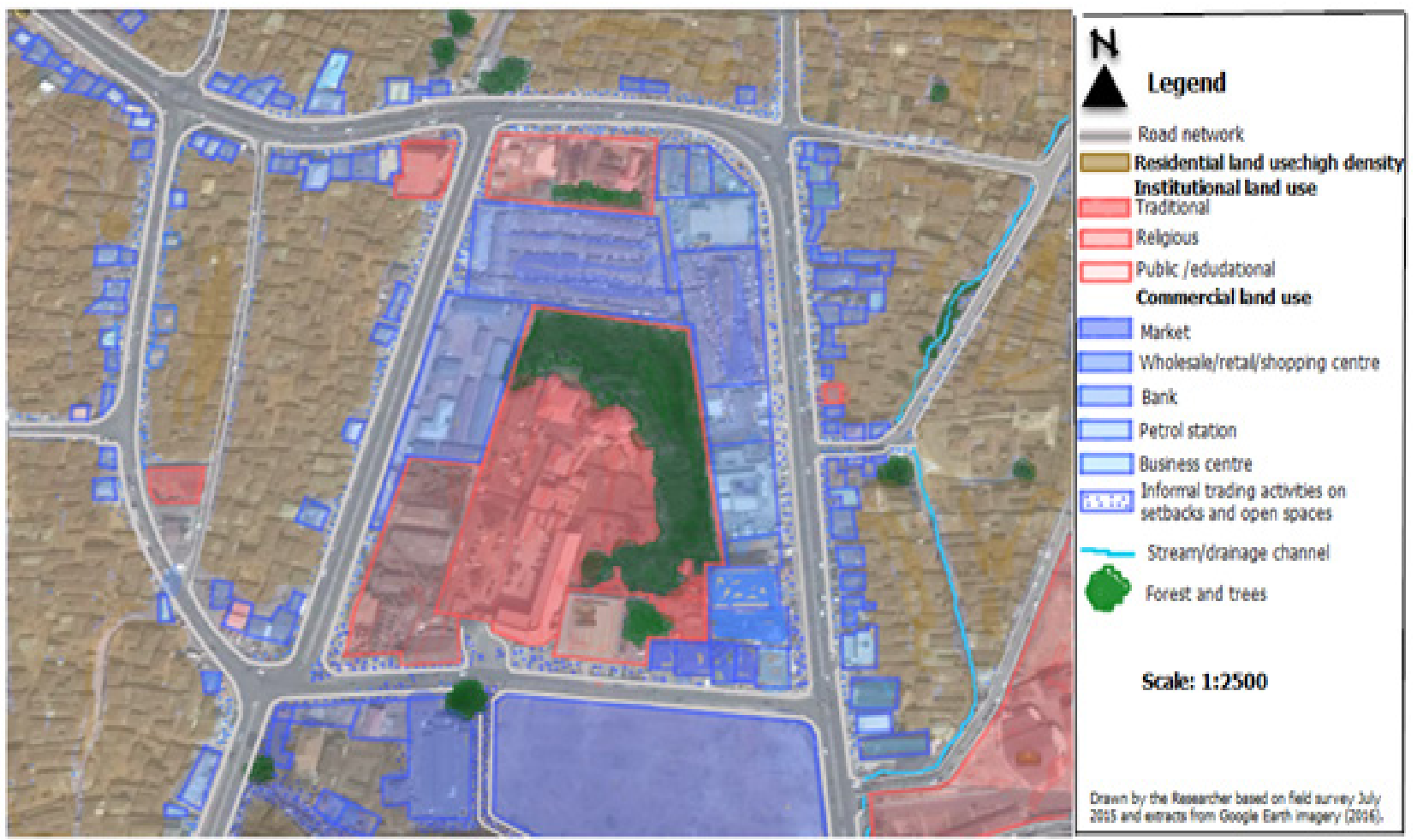

Source: Drawn by Author based on field survey July 2015 and extracts from Google Earth imagery (2016).

Figure 3. The morphology of places in the core/old areas (COAs) in Ado-Ekiti 


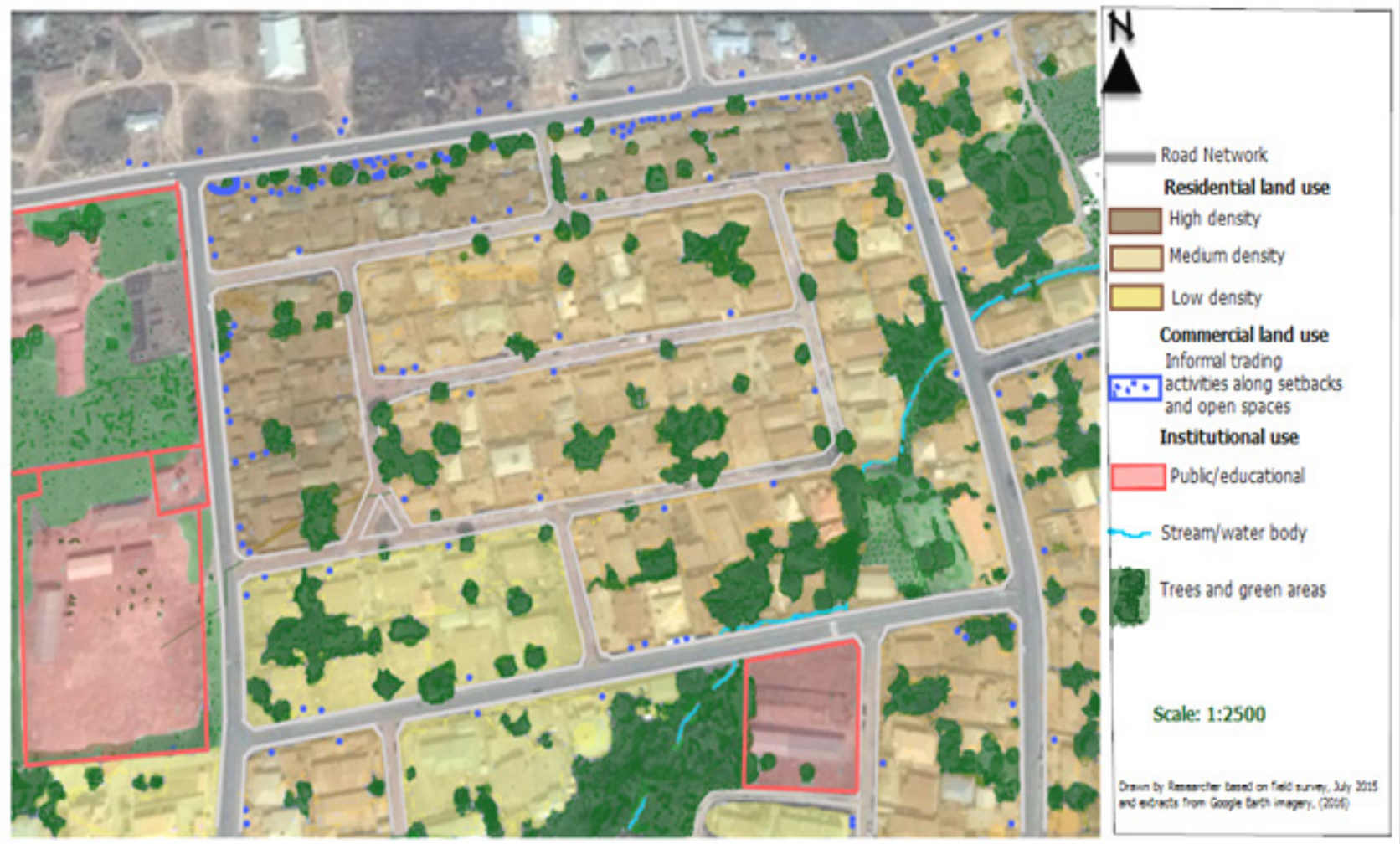

Source: Drawn by Author based on field survey July 2015 and extracts from Google Earth imagery (2016).

Figure 4. The morphology of places in the planned residential areas (PREs) in the city.

Beyond these, the city expands uncontrollably into the surrounding region with attendant vegetal destruction as typified by amorphous development along Ireje River basin within a period of ten year, captured by satellite imageries in Figures 5 and 6. Findings show that there is no conscious or commensurate replacement, which is manifested in the gross inadequacy or total lack of open green spaces in the city. This corroborates a recent study (Ojo-Fajuru \& Adebayo 2016), which establishes that built-up areas and outlying regions of Ado-Ekiti are characterized by absolute vegetal removal, encroachment on setbacks and open spaces, and gross inadequacy or total lack of green spaces. In effect, land uses in the city setting are mostly bare and choked up, with few or no greenery.

Research findings expose the quantitative deficiency of recreational land use in the study area. It is quite revealing that this type of land use is virtually non-existent within the COAs as shown in Table 2 below. It is revealed that recreational land use, in the realm of public open space, is scanty, constituting a paltry $1.98 \%$ in the spatial structure of the city. Majority $61.27 \%$ respondents also affirm the gross deficiency of organized open spaces, giving credence Ojo-Fajuru and Adebayo (2016) finding the existing city spatial structure exhibiting unplanned development insufficient public open spaces and green infrastructure, which reduce livability and attraction as a great place in Ado-Ekiti. Findings also reveal only $9.94 \%$ of houses meet the legal requirement of not exceeding $40 \%$ plot coverage, while the vast majority $90.06 \%$ falls short of the requirement, indicating abysmally low compliance rate of $11.04 \%$, and implying an urban landscape devoid of open spaces around buildings as obvious in closely built areas of the core and new development zones. The research exposes houses with less than 4.5 metres (14.76 feet) minimum front setbacks, and not up to 3 metres(9.84 feet) left side, right side, and rear standard air spaces were about two-third of the sampled buildings, occupying more than two-third of core areas, nearly half in new development areas, and about one-quarter in planned estates. 


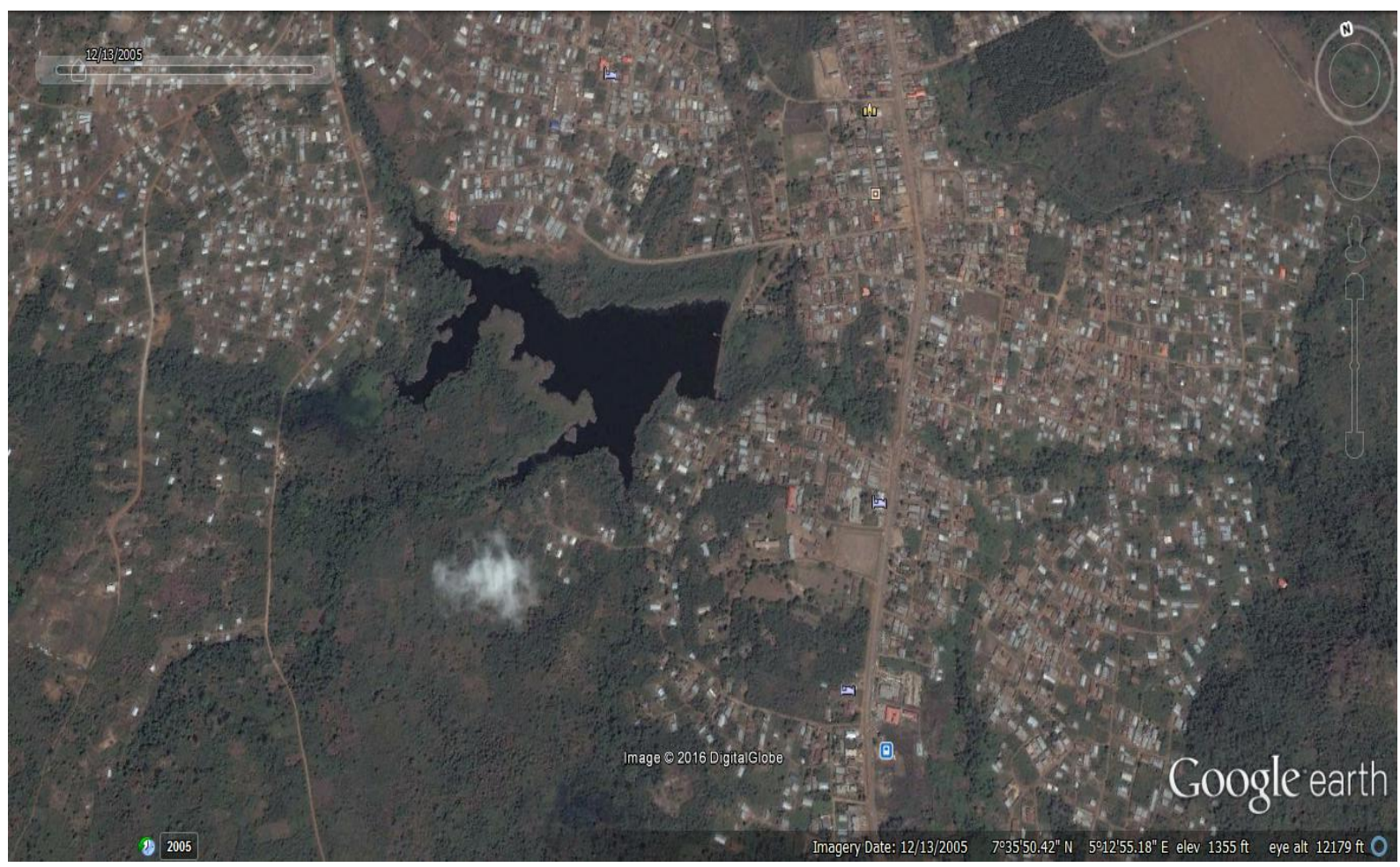

Source: Google Maps, 2016.

Figure 5. Satellite imagery of Ado-Ekiti showing green areas along Ireje River basin in 2005

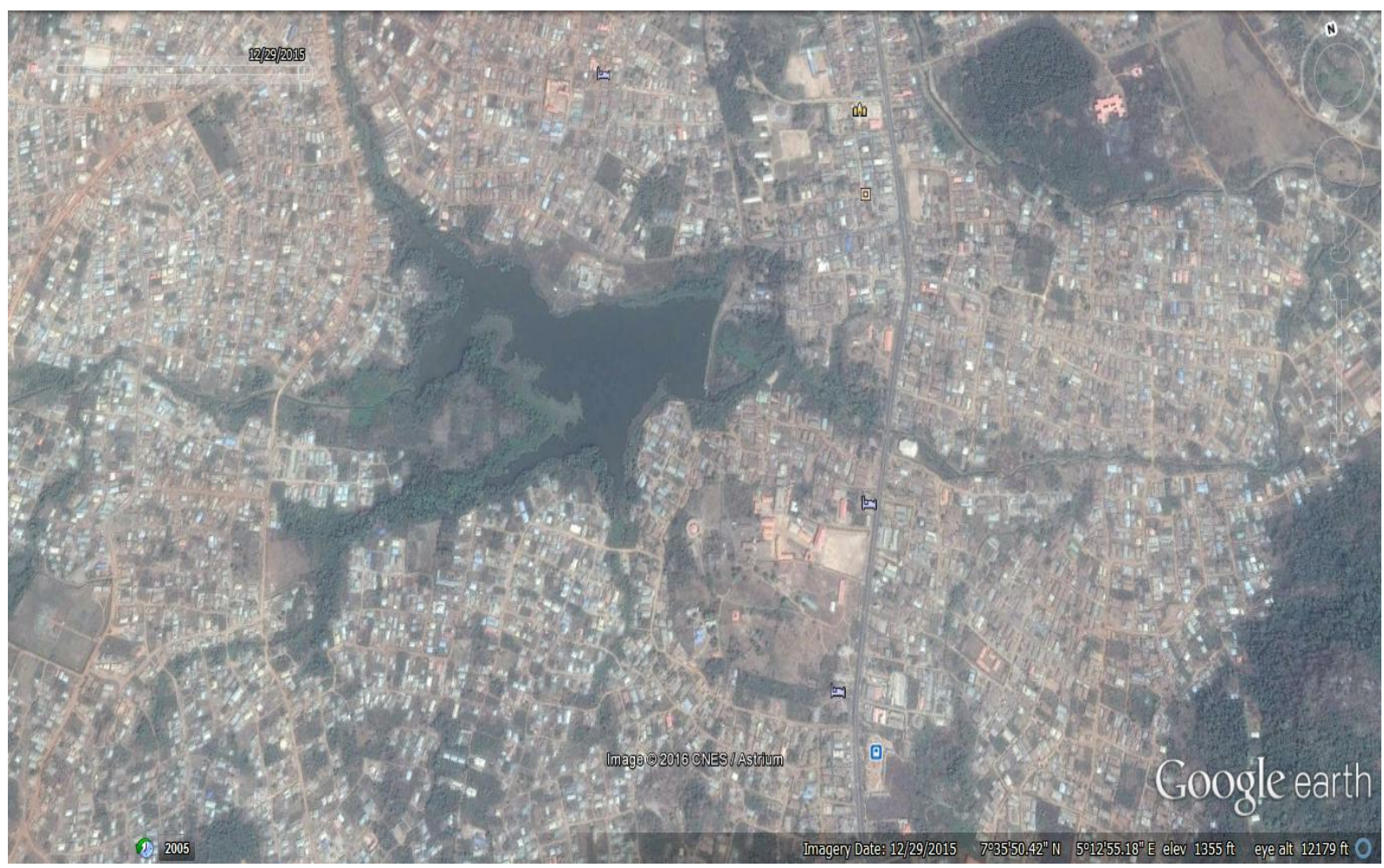

Source: Google Maps, 2016.

Figure 6. Satellite imagery of Ado-Ekiti revealing the subtraction of open green areas for amorphously expanding residential districts with scanty open spaces along Ireje River basin in 2015 
Table 2. Recreational land use is scanty in the spatial structure of morphological zones of the city.

\begin{tabular}{|c|c|c|c|c|}
\hline $\begin{array}{c}\text { Morphological } \\
\text { Zone }\end{array}$ & $\begin{array}{c}\text { Total No. of } \\
\text { Respondents }\end{array}$ & $\begin{array}{c}\text { No. of } \\
\text { Responses } \\
\text { for } \\
\text { recreational } \\
\text { land use }\end{array}$ & $\begin{array}{c}\% \\
\text { within } \\
\text { Zone }\end{array}$ & $\begin{array}{c}\% \\
\text { Overall }\end{array}$ \\
\hline $\begin{array}{c}\text { Core/old areas } \\
\text { (COAs) }\end{array}$ & 1290 & - & - & - \\
\hline $\begin{array}{c}\text { New } \\
\text { development } \\
\text { areas (NDAs) }\end{array}$ & 1560 & 30 & 1.92 & 0.90 \\
\hline $\begin{array}{c}\text { Planned } \\
\text { residential } \\
\text { estates (PREs) }\end{array}$ & 474 & 36 & 7.60 & 1.08 \\
\hline Total & 3324 & 66 & & 1.98 \\
\hline
\end{tabular}

Source: Field survey, July 2015.

Contrariwise, buildings having minimum front setbacks of 4.50 metres (14.76 feet) or more, and left side, right side, and rear air spaces measuring 3 metres ( 9.84 feet) and above, ranged between one-third and a quarter in the study area, but more available in planned estates, averagely occurring in the new development areas, and sparsely punctuating the core/old areas. This indicates choky massing of building, and drastic reduction or absolute lack of open space for landscaping, which epitomizes the dearth of greenery the inner city. The research establishes that public open spaces, which should have been forests and greens, valuable for air purification, surface drainage, and recreation, are quantitatively inadequate, and qualitatively deficient, with attendant implications on scenic beauty, environmental quality, and lost employment creation and income generation in tourism in Ado-Ekiti.

\subsection{The Magnitude and Factors of Encroachment on Public Spaces}

The study establishes $55.21 \%$ high of encroach on public spaces such as squares, setbacks and open spaces, developed into makeshift or permanent structures mostly for commercial purposes without permission (see Figure 3). Findings show uncontrolled occupation of every available space along major roads including sidewalks, and even roadways, where informal commercial activities recorded $59.44 \%$ and $61.02 \%$ in the core and new development areas respectively, as depicted in Figure 7. 
Development Control Regulations Compliance: Paradigm Change to Reinvent

Disrupted Public Spaces and Make Future Great Place in Ado-Ekiti, Nigeria

Table 3.Nature or type of encroachment on setbacks and open spaces in Ado Ekit

\begin{tabular}{|c|c|c|c|c|c|c|c|c|c|c|c|c|c|c|}
\hline $\begin{array}{l}\text { Existing nature } \\
\text { or type of } \\
\text { encroachment }\end{array}$ & Residential use & $\begin{array}{l}\% \text { within } \\
\text { zone }\end{array}$ & $\begin{array}{c}\text { Trading } \\
\text { activities }\end{array}$ & $\begin{array}{c}\% \text { within } \\
\text { zone }\end{array}$ & $\begin{array}{c}\text { Work-shop/lig } \\
\text { ht industry }\end{array}$ & $\begin{array}{c}\% \text { within } \\
\text { zone }\end{array}$ & $\begin{array}{l}\text { Religious } \\
\text { use }\end{array}$ & $\begin{array}{l}\% \text { within } \\
\text { zone }\end{array}$ & $\begin{array}{l}\text { Used as } \\
\text { refuse } \\
\text { heap }\end{array}$ & $\begin{array}{c}\% \text { within } \\
\text { zone }\end{array}$ & $\begin{array}{c}\text { Other } \\
\text { uses }\end{array}$ & $\begin{array}{l}\% \text { within } \\
\text { zone }\end{array}$ & Total & $\begin{array}{c}\% \text { within } \\
\text { zone }\end{array}$ \\
\hline COAs & 91 & 8.46 & 639 & 59.44 & 79 & 7.35 & 114 & 10.61 & 55 & 5.12 & 97 & 9.02 & 1075 & 41.08 \\
\hline NDAs & 97 & 8.69 & 681 & 61.02 & 155 & 13.89 & 97 & 8.69 & 43 & 3.85 & 43 & 3.85 & 1116 & 42.64 \\
\hline PREs & 209 & 49.06 & 125 & 29.34 & 13 & 3.05 & 13 & 3.05 & 36 & 8.45 & 30 & 7.04 & 426 & 16.28 \\
\hline TOTAL & 397 & 15.17 & 1445 & 55.21 & 247 & 9.44 & 224 & 8.56 & 134 & 5.12 & 170 & 6.50 & 2617 & 100.00 \\
\hline
\end{tabular}

Source: Field Survey, July 2015 
The PREs exhibit a low rate of $29.34 \%$. Similar trend of encroachment was revealed along minor and access roads, which are clogged with illegal commercial uses. Furthermore, $15.17 \%$ of encroached public open spaces are used for residential purposes; informal, unpermitted workshops, light industries and services occupy $9.44 \%$; religious use thrive on $8.56 \% ; 5.12 \%$ is used as refuse heaps, while other sundry uses cover $6.5 \%$ in the city, as shown in Table 3.

The study establishes that $92.24 \%$ encroachment, yielding myriad of illegal development on public spaces, negates every legal standard, reduces circulation spaces, undermines greenery, and endangers lives and properties. Findings reveal major causal factors for incessant encroachment as ignorance and carefree attitude to good quality environment $(34.65 \%)$, laxity of government organs on development matters $(31.77 \%)$, developers' desire for economic benefit $(15.19 \%)$, increasing human activities requiring space $(13.16 \%)$, and the nefarious activities of land speculators poaching the city (4.48\%).

\subsection{Levels of Awareness and Compliance with Development Control Regulations in the City}

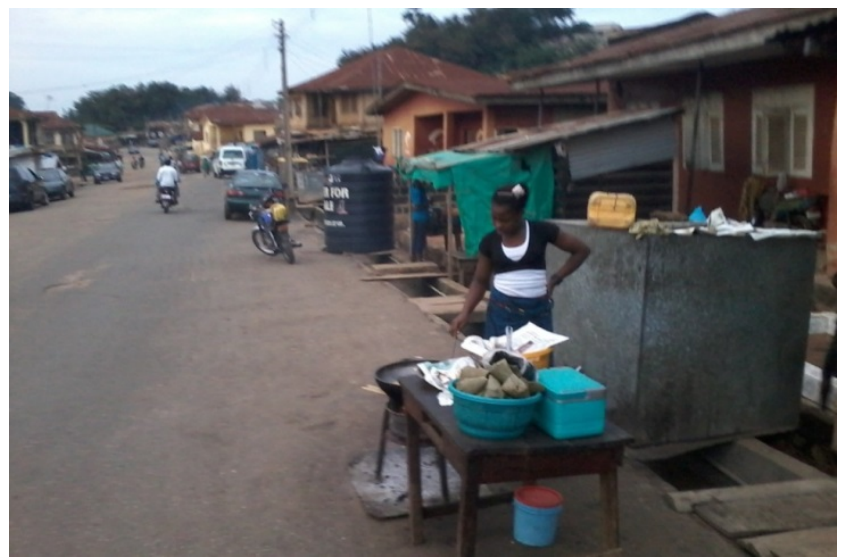

Source: Field survey, July 2015.

Figure 7.With illegal structures attached to houses on setback spaces; water (for sale) tanks across the drainage channel; cooking, frying and trading taking place on the road surface, it is business as usual backed by high-handed audacity and impunity at Kajola Street in the new development area of Ado-Ekiti.

The research reveals high level awareness of physical planning laws, regulations and codes regarding the obtainment of planning permits prior any development, provision and maintenance of public spaces and greens. The study finds only $47.86 \%$ of houses examined had planning permission from the approving authority, $21.26 \%$ never had development permits, while $30.85 \%$ claimed ignorant of acquiring approved building plans, cumulating to $52.11 \%$ for houses without approved plans. This indicates that more than half of houses in the city were essentially constructed without approved plans. Findings expose a disconnection between $72.00 \%$ majority claiming awareness of physical planning regulations, and the low level of compliance to the dictates of the laws. Conversely, $17.04 \%$ are not aware of any planning regulations, while $10.96 \%$ were apathetic. Findings establish that those who are aware of the laws deliberately flaunt them along with those that are not aware due to the laxity of the control agency. It proves that people willfully and defiantly engage in encroachment with impunity and cheer audacity, taking advantage of the weakness of the Control Agency (see Figure 7).

The research establishes high levels of contravention, encroachment and non-compliance, confirming that the statutory provisions of existing laws and regulations are of little effect in the control of development on public open spaces in the city.

\subsection{The Need to Reclaim Encroached Public Spaces and Reestablish Green Places}

The research establishes cases of contraventions and encroachment resulting to the relatively low proportion of public open spaces and greenery in the spatial structure of the city. It reveals indiscriminate vegetal removal and usurpations of public spaces, contrary to statutory provisions. Findings establish over $70 \%$ awareness of the dictates of law, which are blatantly contravened with impunity to meet challenges of daily survival, thereby resulting to waves of illegal structures clogging public spaces in the urban matrix. The study exposes the ineffectiveness of government apparatus to control development, which perpetrates encroachment and amorphous expansion. The study reveals divided opinion on the effort of government at savaging encroached setbacks and open spaces, which $20.18 \%$ viewed as poor, while $53.71 \%$ majority assessed as fair, just as good rating was only $19.25 \%$. It is indicated that the development control authority is not performing well in its effort to reclaim the lost spaces, even as it is helpless in curtailing encroachment. The implication is that government cannot do it alone without the support of the people.

\section{Research Contribution}

The research generates fresh data on the existing state of public spaces in the spatial structure, wherein three distinctive morphological zones, dominated by residential land use, were identified in Ado-Ekiti. The study documents evidence that the city expands uncontrollably into the surrounding region with attendant vegetal destruction, which is manifested in the gross inadequacy or total lack of open green spaces. Vital information on the acute shortage of recreational land use in the study area is given. The revelation is original that, less than $10 \%$ of houses did not exceed statutory $40 \%$ plot coverage, while over $90 \%$ contravened. Data series generated, exposing the general inadequacy of setbacks and air spaces around 
buildings, and resulting to quantitative and qualitative deficiency of public open spaces, are novel. The established high magnitude of encroachment on public spaces, mostly for commercial purposes, and factors responsible, emanate from the study. The research throws up unique information on the high level awareness of physical planning laws, regulations and codes on development control and public space provision, which does not correlate with established high levels of non-compliance manifested in highhanded contravention and public space encroachment. The exposure of the ineffectiveness of extant planning laws and regulations, warranting indiscriminate vegetal removal, and evasion of public spaces, with attendant low proportion of open spaces and greenery in the spatial structure of the city, are new findings from the study. Also derived from the research are the incapability of the development control authority to curb contravention and encroachment on public spaces; and the low rating on efforts to reclaim the lost spaces. Equally innovative is the establishment of the need for concerted effort to reclaim encroached public spaces and reestablish green places in Ado-Ekiti. The proposed Strategic Urban Greening Intervention Model for Socio-Economic and Environmental Sustainability in Ado-Ekiti Green City can be replicated, not only in other cities in Nigeria, but also in sub-Sahara Africa.

\section{Discussion \& Concluding Remarks}

The need for a paradigm shift, to bring about strict compliance with development control regulations, and reestablish public spaces usurped in Ado-Ekiti, is central to this research. This is geared towards transforming these spaces to green places that accommodate socio-economic activities, and promote the ideals of livable, inclusive and sustainable city. With the people wholeheartedly supporting effective reversal of the culture of contravention and encroachment, being the established root cause of disorderliness and environmental degradation; and embracing the retrofitting of lost spaces, the ugly state of the city will be replaced with people-friendly environment that guarantees Ado-Ekiti as a future great city. Workable recommendations and implementable proposals are indispensible to attain this noble course.

\subsection{Attitudinal Change and Civic Reorientation}

Firstly, there must be attitudinal change involving all facets of Nigerian life in order to attain any meaningful achievement. Nigerians must key into the change mantra of the Federal Government to turn around the scourges of abnormalities, impunity and corruption that have continuously clogged the wheel of national development. Since change is the only permanent thing, the people must be ready to change from old ways of doing things, toe the line of discipline, patriotism, honesty, transparency, due process and orderliness; and break the jinx of defiance, impunity, fraud, underdevelopment, poverty, squalor and environmental degradation stalling significant national progress. The future of Nigeria, and those of generations yet unborn, rest in the hands of the present generation of Nigerians.

\subsection{Compliance with the Rule of Law}

With the people's state of mind prepared to accept, embrace and condone change, the state government should review extant laws periodically, enact new ones when necessary, and implement them to the letter to curb impunity, audacity and lawlessness in Ekiti State. The Government should cultivate the will power and take advantage of the current change agenda of the Federal Government and enforce development control regulations in the strict sense to instill effectiveness, consistency, stability and sustainability. The success story of the Fashola Administration that tamed Lagos Megacity with greening started with the implementation of existing laws of the State to the last iota, rather than enacting new ones. There were hues, cries, and even name-calling by dissenting voices, but the determination and consistency of government, headed by a Senior Advocate of Nigeria (SAN), brought about the wind of greenly change in the city environment as dividends of democracy.

Nigerians are law abiding, conscious of the law, become more courteous when the law is strictly enforced, and are wont to comply once they know that culprits will be arrested, prosecuted and punished. The rule of law should hold at all times and everywhere, no matter how highly placed the offender could be. It will be recalled that in the first coming of General M. Buhari as military Head of State in 1984, the War Against Indiscipline (WAI) initiative was lunched to stamp out corruption that bedeviled the country. The campaign was yielding results, and the people have started adjusting to honesty, orderliness and cleanliness. This euphoria of change for a better Nigeria was short-lived when the Babangida Administration stalled the process in 1985, jettisoned the programme, and commenced business as usual. Thirty years after, and having regained the helm of affairs as a democratically elected civilian President, the war that the Buhari Administration is waging against corruption and indiscipline, since inception in May 2015, has started yielding results. Ekiti State Government should emulate and replicate this feat to curb illegal development and public space encroachment, and ensure development control regulations compliance as paradigm change to revamp the poor state of the capital city environment.

\subsection{Governance as True Continuum for Capacity Building}

Making governance a continuum to boost capacity 
building for the development control department is germane to the success of this city reinvention programme. The developmental policy somersault should be prevented, whereby successive administrations in State abandon good policies initiated by predecessors on the ground of political differences, or even personality clashes. This unprogressive saga is currently playing out in the State whereby the ruling Fayose Administration has already abandoned the flourishing greening initiatives of the immediate past Fayemi Administration, which should have been better retained, maintained and sustained to the betterment of the state capital, and benefit of the people. All need be done is capacity strengthening for the development control agency in the areas of manpower and monitoring equipment like vehicles, cameras, internet facilities and relevant gadgets for efficiency, wider coverage and improved performance.

\subsection{Adopt the Ado-Ekiti Comprehensive Greening and Spatial Regeneration Intervention Master Plan as a Model for African Cities}

As recently proposed elsewhere (Ojo-Fajuru \& Adebayo, 2014; Ojo-Fajuru\& Adebayo 2016), the proposed Ado-Ekiti Comprehensive Greening and Spatial Regeneration Intervention Master Plan (hereafter referred to as 'Ado-Ekiti Green City Master plan'),made pursuant to the Strategic Urban Greening Intervention Model for Socio-Economic and Environmental Sustainability in Ado-Ekiti Green City, and as a component of the Master Plan of Ado-Ekiti, should be subjected to public critique before adoption and conscientious implementation. Appropriate enactment should be adopted within the framework of the Ado-Ekiti Green City Master plan to chart the course of all organs of implementation, and as well legalize and support the breaking up of bare and hard surfaces for replacement with plants and flowers to reintroduce nature and biodiversity into hitherto exposed areas of the city. All open spaces naturally or incidentally occurring, including setbacks to roadways, utilities and water bodies, and those reclaimed from illegal development, as well as slopes, should be converted into massive urban forest and green areas. These should be accomplished by embarking on massive tree planting and grassing of these public spaces and maintenance of naturally occurring patches along various categories of roads to create greenways, parkways, promenades and boulevards. These will be integrated with vegetated, re-established and newly created gardens, squares and parks within the CBD and residential districts to form a network of interconnecting greenbelts, which are appropriately furnished to create great places for citizens' recreation. Selected socio-economic activities should be incorporated and controlled in designated places to accommodate displaced roadside and itinerant traders and thereby promote inclusiveness, services and improved city economy.

It is believed that with change-oriented public support and participation in development control regulations compliance, coupled with government's proactive approach to development matters, the unwholesome cityscape will be savaged, when reclaimed spaces are reestablished and maintained as dynamic green places, where organised recreational and commercial activities flourish to reinvent Ado-Ekiti as a future great capital city.

\section{Acknowledgements}

Some government officials, heads of communities, leaders of associations, field supervisors, and research assistants, among others, played important roles while conducting this research. Their names are too numerous to be listed within this limited space. However, some of them are worth mentioning for appreciation such as: Dr. Olugbenga Faseluka, Ekiti State Head of Service; Mr. Bunmi Famosaya, Former Ekiti State Head of Service, and currently Special Adviser, Governor's Office, Ekiti State; Hon. Bisi Kolawole, Ekiti State Commissioner for Environment; Prince Otitoju Tayelolu, Ekiti State Commissioner for Lands; the Elejigbo of Ijigbo Quarters, Ado-Ekiti; the Elemunkanse, and Alarineni of Oke-Ila Quarters, Ado-Ekiti. Others include Dr. A. M. Olaseni, former Deputy Rector (Academic), Yaba College of Technology, Yaba, Lagos; Dr. Wale Alade, Coordinator, Post Graduate Programme, Department of Urban and Regional Planning, University of Lagos; Professor J. A. B. Olujimi, Dean, School of Environmental Technology, Federal University of Technology, Akure; Tpl. Sanmi Adeoti, Head of Department, and Final Year students, H.N.D, Programme, Department of Urban and Regional Planning, Federal Polytechnic, Ado-Ekiti; Also worthy of special thank is Prof. Mathew Dayomi, former Head of Department, Discipline of Planning, School of Built Environment and Development Studies, University of KwaZulu-Natal, Durban, South Africa for his useful critique and passionate interest in the research project. The financial and logistic support usually received from Dr. (Mrs.) Dorcas Ajayi, former Head of Department, Biological Sciences, College of Education, Ikere-Ekiti, and Mr. Yemi Adesuloro, Manager, Diamond Bank PLC, Lagos, and the secretarial prowess and ever ready assistance of Ms. Sivani Naidoo, Ambro Afrique Consultants, Durban are hereby acknowledged. Most of all, to God is the glory, honor and adoration, for His mercy endures forever.

\section{REFERENCES}

[1] Adebayo, Jegede \& Ogundele 2015, 'Environmental Laws in Nigeria: Negligence and Compliance on Road 
Transportation Land Use Planning Pattern in the South-South Geo-political Zone', Donnish Journal of Law and Conflict Resolution, 1(3) 18-28, available at: http://www.donnishjournals.org/djlcr/pdf/2015/october/Ade bayo-et-al.pdf [accessed: 28 April 2016].

[2] Alao, T 2016, 'Professionals urge compliance to Lekki master plan' The Guardian 18 January, p. 58 available athttp://guardian.ng/property/professionals-urge-complianc e-to-lekki-master [accessed: 25 April 2016].

[3] Aluko, O 2011, 'Development Control in Lagos State: an Assessment of Public Compliance to Space Standards for Urban Development', African Research Review: International Multidisciplinary Journal, 5 (5), 22, 169-184 available at: http://dx.doi.org/10.4314/afrrev.v5i5.14 [accessed: 28 April 2016].

[4] Aziken, E, Akinrefon, D, Kumolu, C \& Oke, G 2016, 'I feel your pains Buhari tells Nigerians at the Vanguard Awards', Vanguard News, 9 April, p. viewed 17 April 2016, http://www.vanguardngr.com/2016/04/feel-pains-buhari-tel 1s-nigerians-vanguard-awards/

[5] Bascom, W. 1962, 'Some Aspects of Yoruba Urbanism'. American Anthropologist 64 (4): 699-709.

[6] Blier, SP 2012, 'Art in ancient Ife, Birthplace of the Yoruba', African Arts. 45: 70-85. [Online] Available: http://scholar.harvard.edu/files/blier/files/blier.pdf[Accesse d 30 November, 2016].

[7] Breese, G 1966, Urbanization in newly developing countries, Modernization of Traditional Societies Series, Englewood Cliff, New Jersey, Prentice-Hall, Inc.

[8] Dmochowski, Z. 1990, An Introduction to Nigerian Traditional Architecture, Volume Two: South-West and Central Nigeria, Ethnographical/ The National Commission for Museums and Monuments

[9] Enisan, O \& Ogundiran, A 2014, 'Implications of Urban and Regional Planning Laws on Urban Renewal Projects in Akure, Nigeria', Journal of Environment and Earth Science, 4 (22) 46-53 available at: www.iiste.org/Journals/index.php/JEES/article/viewFile/18 260/18944 [accessed: 28 April 2016].

[10] Fadamiro, JA 2002, 'Open Space Concept and the Importance for Effective Urban Environment: A Case Study of Akure, Nigeria', Journal of Environmental Technology, $1(1 \& 2), 79-90$.

[11] Falade, J 1985, Nigeria's Open Spaces: An Inquiry into their Evolution, Planning and Landscape Qualities, Ph.D Thesis, University of Edinburgh.

[12] Federal Government of Nigeria (FGN) 1992, Nigerian Urban and Regional Planning Law, Decree No. 88, Federal Government Press, Lagos.

[13] Gianoluca C 2016, The Law of Public Spaces Portland: Sustasis Foundation, available: http://www.sustasis.net/Crispi.docx [Accessed 11 March 2016].

[14] Gray, J 2011, "Public Nuisance Law: a Historical Perspective" available at: www.wikipedia.org [Accessed May 2011].

[15] Ibrahim, RB \& Toyobo, AE 2014, 'Appraisal of
Development Control Activities in Ogbomoso South Local Government, Oyo State, Nigeria', Asian Journal of Science and Technology, 5(6), 313-319, available at: http://www.academicjournals.org/ajpsir [accessed: 28 April 2016].

[16] John Paul II, 1979 Encyclical Letter: Redemptor Hominis, 15, AAS 71, 287.

[17] Kent, E. 2015, Placemaking as a New Environmentalism: Reinvigorating the Environmental Movement in the 21st Century, New York: Project for Public Spaces, available at: www.pps.org/reference/placemaking-as-a-new-environmen talism/ [accessed: 18 March 2016].

[18] LASG 1986, Town and Country Planning (Building Plan), L.S.L.N. No 15, Government Press, Lagos.

[19] Law Dictionary 2016, 'Compliance'. Available: http://www.merriam-webster.co/dictionary/compliance [Accessed 28 April 2016].

[20] Mabogunje, AL 1962, Yoruba Towns, Ibadan, Ibadan University Press.

[21] Nigerian Institute of Town Planners (NITP) 2014, State of Planning in Nigeria, Abuja: NITP, available: nitpng.com/pdf\%20docs/soplanning.pdf [Accessed 26 April 2016].

[22] Obateru, OI 2005, Basic Elements of Physical Planning, Penthouse Publications Nig. (Visionary Publishers) Ibadan.

[23] Oduwaye, L 2014, 'Imperatives of the Greening Culture in Contemporary Nigerian Cities', in Building Clean Cities in Nigeria, edited by B. Wahab, N. Atebije, \& I. Yunusa. , Abuja: Nigerian. Institute of Town Planners (NITP) \& Town Planners Registration Council of Nigeria (TOPREC), 181-226.

[24] Ogundele, FO, Ayo, O, Odewumi, SG, \& Aigbe, GO 2011, Challenges and prospects of physical development control: A case study of Festac Town, Lagos, Nigeria, African Journal of Political Science and International Relations, 5(4), 174-178, available at http://www.academicjournals.org/ajpsir [accessed: 28 April 2016].

[25] Ojo, AG 1966, Yoruba culture: A geographical analysis, Ile-Ife and London: University of Ife and University of London Press.

[26] Ojo-Fajuru, JO 2003, Planning for Recreational Open Spaces in Ado-Ekiti, Nigeria, PGD Dissertation, Federal University of Technology, Akure.

[27] Ojo-Fajuru, JO 2012, 'Green Landscaping Techniques: the Leeway from Pollution and Climate Change to Urban Landscape Sustainability in Lagos Mega-city', Global Climate Change, Environmental Pollution and Food Security: Implications for Africa: proceedings on $2^{\text {nd }}$ Biennial International Conference, $18^{\text {th }}-20^{\text {th }}$ April, 2012, Environmental Research Group, Lagos.

[28] Ojo-Fajuru, JO \& Adebayo, AA 2014, Greening and Furnishing Setbacks, Open Spaces and Parks towards Making Great Places to Promote Livability and Inclusiveness in Regional Capital Cities: the Case of Ado-Ekiti and Akure, Nigeria. A Paper presented at the Planning Africa Conference 2014, International Conference on Making Great Places, organised by South Africa 
Planning Institute (SAPI) held at the International Conference Center, Durban, South Africa between 19th and 22nd October, 2014.

[29] Ojo-Fajuru, JO \& Adebayo, AA 2016, 'Recovering Lost Socio-cultural Spaces to Reestablish Sustainable Green Places and Reinvent Ado-Ekiti, Nigeria as a Great City of Tomorrow', in 7th Planning Africa Conference 2016-Making Sense of the Future: Disruption and Reinvention, South African Planning Institute, Johannesburg.

[30] Olanrewaju, DO 1990, Spatial Distribution of Urban deprivation in Akure, Ondo State, Nigeria. Ph.D Thesis, University of Sheffield, pp 40-43.

[31] Olaseni, AM \& Ojo-Fajuru, JO 2015, Course Brief, Lecture notes distributed on URP 426: Professional Practice, Yaba College of Technology, Yaba, Lagos, on 09 December 2015.

[32] Onokerhoraye, AG 1976, Urban Environmental Problems and Planning Strategies in Tropical Africa, Ibadan, Nigerian Institute of Social and Economic Research.

[33] Onokerhoraye, AG 1995, Urbanisation and Environment in Nigeria: Implications for Sustainable Development, the Benin Social Science series for Africa, Benin City, University of Benin.

[34] Osinbajo, Y 2016, VP says change is irreversible, Abuja:
NAN, Pulse News Agency Local, New Agency of Nigeria, available at:http://pulse.ng/local/osinbajo-vp-says-change-is -irreversible-id4953702.html [accessed: 29 April 2016].

[35] Oxford Advanced Learner's Dictionary, $6^{\text {th }}$ Edition 2000, Oxford: Oxford University Press.

[36] Safer Spaces 2016, Public spaces: More than 'just space, South Africa: SS, available at: http://www.saferspaces.org.za/resources [accessed: 11 March 2016].

[37] UN Habitat 2015, Urban October 2015 Background Paper: Public Space for All-Designed to Live Together, Nairobi: UN Habitat, available at: http://www.unhabitat.org/public-spaces-for-all-2/ [accessed: 18 March 2016].

[38] Urban Dictionary, 2016, Public space Available: http://www. urbandictionary.com/define.php?term=public + space\&defid $=983396$ [Accessed 28 April 2016].

[39] Wikipedia, 2016a, Regulatory Compliance, Available:https://en.wikipedia.org/w/index.php?title=Regul atory_compliance\&oldid $=716749428$ [Accessed 28 April 2016].

[40] Wikipedia, 2016b, Compliance Available: https://en.wikipedia.org/w/index.php?title=Compliance\&ol did=665480149 [Accessed 28 April 2016]. 